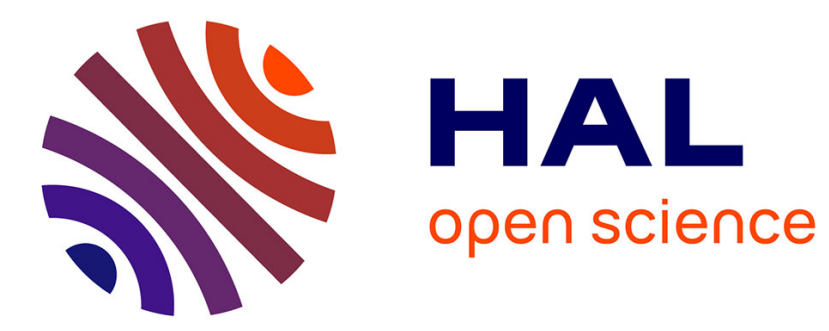

\title{
Localization and characterization of the novel protein encoded by C20orf3
}

Aysegul Ilhan, Wolfgang Gartner, Anastasiya Nabokikh, Teodora Daneva, Otto Majdic, Gerald Cohen, Georg A. Böhmig, Wolfgang Base, Walter H. Hörl, Ludwig Wagner

\section{To cite this version:}

Aysegul Ilhan, Wolfgang Gartner, Anastasiya Nabokikh, Teodora Daneva, Otto Majdic, et al.. Localization and characterization of the novel protein encoded by C20orf3. Biochemical Journal, 2008, 414 (3), pp.485-495. 10.1042/BJ20080503 . hal-00478994

\section{HAL Id: hal-00478994 https://hal.science/hal-00478994}

Submitted on 30 Apr 2010

HAL is a multi-disciplinary open access archive for the deposit and dissemination of scientific research documents, whether they are published or not. The documents may come from teaching and research institutions in France or abroad, or from public or private research centers.
L'archive ouverte pluridisciplinaire HAL, est destinée au dépôt et à la diffusion de documents scientifiques de niveau recherche, publiés ou non, émanant des établissements d'enseignement et de recherche français ou étrangers, des laboratoires publics ou privés. 


\section{LOCALIZATION AND CHARACTERIZATION OF THE NOVEL PROTEIN ENCODED BY C20orf3}

\section{Aysegul Ilhan ${ }^{* \dagger}$, Wolfgang Gartner ${ }^{* \dagger}$, Anastasiya Nabokikh ${ }^{*}$, Teodora Daneva ${ }^{\ddagger}$, Otto Majdic $^{* \S}$, Gerald Cohen ${ }^{*+}$, Georg A. Böhmig ${ }^{*+}$, Wolfgang Base ${ }^{*+}$, Walter H. Hörl ${ }^{*+}$, Ludwig Wagner ${ }^{* \dagger}$}

*Medical University of Vienna, AUSTRIA, ${ }^{\dagger}$ Department of Internal Medicine III, Division of Nephrology and Dialysis, Vienna, AUSTRIA, ${ }^{\ddagger}$ Bulgarian Academy of Science, Sofia, Bulgaria, ${ }^{\S}$ Department of Immunology, Vienna, AUSTRIA

\section{Address of correspondence:}

Ludwig Wagner, MD

Medical University of Vienna, Department of Internal Medicine III

Waehringer Guertel 18-20, A-1090 Vienna, Austria

Tel.: 00431404004341

Fax: 00431404007790

E-mail: ludwig.wagner@meduniwien.ac.at 


\begin{abstract}
In this study, we characterized the gene product of open reading frame 3 encoded at human chromosome 20 (C20orf3), which represents a member of the lactonohydrolase super family.

Multiple tissue Northern showed ubiquitous expression of the $2.4 \mathrm{~kb}$ transcript coding for 416 amino acids (aas), with highest levels in human liver, placenta and the kidney. After recombinant production of protein variants in E.coli and insect cells, antibodies directed against different epitopes within the C20orf3 gene product were generated. Using these immunoreagents the protein expression was demonstrated in the liver, glomerula and tubular structures of the kidney as well as in endothelial cells and arterial wall. Positive staining was also observed at the pancreatic islet of Langerhans. Via immunoblotting we identified three size variants. In line with the results of in silico analysis demonstrating a single transmembran spanning sequence (aas 40-61) at the N-terminus of the full length protein, FACS cell surface staining confirmed a mainly extra cellular localization of the full length protein. Sucrose gradient cell fractionation revealed membrane association of the dominant $50 \mathrm{kDa}$ variant in Hep G2 and Rin-5F cells. The finding of a strong arylesterase activity with B-napthyl acetate and phenyl acetate of the C20orf3 protein containing fractions suggests potential involvement of this protein in enzymatic processes. C20orf3 promoter driven reporter assays, which were verified by gene-specific RT-qPCR showed a strong inhibitory effect of human serum on transcription using the human embryonic kidney cell line Hek 293.

In conclusion, we characterized the structure and expression pattern of the C20orf3 gene product. According to a series of analogies with $\mathrm{PON}$ family members, we speculate that the $\mathrm{C} 20$ orf3 gene product represents a new member of this important protein family present at cellular level.
\end{abstract}

Keywords: C20orf3, PONs, strictosidine synthase, gene cloning, lactonohydrolases, protein purification 


\section{Abbreviations used:}

$\mathrm{Aa}(\mathrm{s})$, amino acid(s);

ATCC, American type culture collection;

C20orf3, chromosome 20 open reading frame 3;

DAPI, 4'6-diamidino-2-phenylindole-2HCl;

DEPC, Diethyl pyrocarbonate;

EST, Expressed Sequence Tags;

GAPDH, glyceraldehyde-3-phosphate dehydrogenase;

GEO-Profile, Gene expression omnibus profile;

GST, glutathione $S$ tranferase;

IPTG, Isopropyl $\beta$-D-1-thiogalactopyranoside;

LDL, Low density lipoprotein;

mAb(56), monoclonal antibody (56);

NCBI, National Center for Biotechnology Information;

Ni-NTA, nickel nitrilotriacetic acid;

PBS, phosphate-buffered saline;

$\mathrm{PCR}$, polymerase chain reaction;

PON, paraoxonase;

RT-qPCR, quantitative real time polymerase chain reaction;

rpm, revolutions per minute;

SNP, single nucleotide polymorphism;

SS, strictosidine synthase 


\section{INTRODUCTION}

The liver and the kidney represent important sites of drug metabolism and detoxification. In addition to the excretory capacity of the kidneys, their involvement in balancing and modifying the plasma protein pool as well as its responsibility for inactivation of bioactive endogenous compounds have been demonstrated.

The renal detoxification process strongly depends on the water solubility of toxins. Therefore, enzymes involved in the attachment of small hydrophilic groups or in hydrolysis, thus inactivating ingested or endogenous potentially toxic compounds, are highly prevalent at this organ. Several such enzymes have been identified and their expression pattern has been characterized. One important group of such detoxification enzymes are paraoxonases (PON), of which three members (PON1-3) have been defined in humans [1]. Highest expression of PON1 and PON3 was found in the liver [2-4], whereas PON2 is also expressed in other organs, e.g the brain and the kidney [5,6]. Although the endogenous substrates of PON family members in mammalians are still not defined, an important role of these enzymes is drug modification via their lactonase activity [7,8]. For example, spirinolactone and distinct statins can be hydrolyzed by PON3 and to a much lower extent by PON1 [9]. Furthermore, dihydrocumarine has been reported to represent the substrate of all three members $[7,8,10]$.

Interestingly, PON1 and PON3 were detectable in the blood [2,4], whereas PON2 was only detected at the cell surface and intracellularly, where it exerts its anti-oxidative properties [6]. An important function of secreted PONs is their association with lipoproteins [11-13]. Thereby it has become evident that PON1 exerts anti-oxidative effects on lipids, thus preventing atherosclerosis $[14,15]$. In addition, PON1 and PON2 polymorphisms which affect the primary structure of the protein and activity $[16,17]$ are associated with changes in the intermediate traits of plasma lipoprotein metabolism [18].

The recent recombinant expression of PON family members has facilitated their structural and functional analysis [19,8]. Interestingly, this protein family uses a helix at the $\mathrm{N}$-terminus either as a transmembrane domain or to associate with lipoproteins $[20,13]$. In line with the drug modifying capacities of PON family members, the similarity of the crystal structures of PON1 and plant strictosidine synthase (SS), namely their six-bladed $\beta$-propeller fold structure, has to be mentioned [20,21]. Plant SS catalyzes the condensation of secologanin and tryptamin to strictosidine, thus being involved in the generation of numerous biological important alkaloids [22]. This enzyme shows similarity with the yet not analyzed gene product of the C20orf3 gene locus and might represent both members of a super-family with lactonohydrolases and paraoxonases [23].

In this article, we describe the cloning and the molecular characterization of the $\mathrm{C} 20$ orf3 gene product representing an up till now undefined protein in humans. Using newly generated antibodies and multiple tissue Northern blotting, the C20orf3 expression pattern is deduced, showing a characteristic, glomerular and tubular expression within the kidney and high levels of hepatocellular presence. Additionally, central nervous system expression and presence at distinct endocrine organs was revealed. Its homology with plant SS and its similarities with the PON family members suggest important functions of this protein in central metabolic processes. 


\section{METHODS}

\section{Cloning of human C20orf3 gene using Gateway and Bac-to-Bac technologies and antibody generation}

Methods of cloning human C20orf3, purification of the protein variants and antibody generation are described in detail at the supplementary section. E. coli BL21 (Invitrogen) and insect cell lines Sf9, High Five (both from Invitrogen) were utilized for protein purification using Gateway and Bac-to-Bac (Invitrogen) technologies, respectively. The resultant human recombinant $\mathrm{C} 20$ orf3 protein was injected into mice and rabbits for monoclonal and polyclonal antibody generation.

\section{Northern Analysis}

For RNA extraction, tissues were homogenized with a Polytron PT 3100 (Kinematica, Littau, Switzerland) tissue homogenizer in TRIzol (GIBCO-BRL). The resultant solution was treated as indicated in the manufacturer's test manual. In brief, TRIzol homogenates were extracted with chloroform and the aqueous phase was transferred into a separate tube for RNA precipitation using isopropanol. After washing in $75 \%$ ethanol, the RNA pellet was dissolved in DEPC treated water and either used immediately for reverse transcription or frozen at $-80{ }^{\circ} \mathrm{C}$.

Multiple tissue Northern blots (BD Biosciences Clontech Palo Alto, CA, USA) containing $2 \mu \mathrm{g}$ mRNA at each lane were hybridised with a 9 exon spanning C20orf3 specific probe. Hybridisation using ULTRAhyb solution was performed according to the manufacturer's instructions (Ambion, Austrin, TX, USA). In brief: After a two hours prehybridisation step at $42{ }^{\circ} \mathrm{C}$ blots were incubated overnight with the ${ }^{32} \mathrm{P}$ labelled probe in $10 \mathrm{ml}$ ULTRAhyb solution and were then washed with NorthernMax Low Stringency Wash Solution \#1 followed by washing with NorthernMax High Stringency Wash Solution \#2 (both from Ambion, Austin, TX, USA). Blots were exposed to x-ray films at $-80{ }^{\circ} \mathrm{C}$ overnight. In order to control for RNA loading the same blots were re-hybridized using a ${ }^{32} \mathrm{P}$ labelled $\beta$ actin probe.

\section{Quantitative real-time PCR}

cDNA generated from HEK 293 (ATCC, CRL-1573), SH-SY5Y (ATCC, CRL-2266), Hep G2 (ATCC, HB-8065), placenta, kidney and liver were used as template in TaqMan gene expression assays. The original cDNA transcript $(1.8 \mu \mathrm{l})$ was used together with $2.5 \mu \mathrm{l}$ of the 20x gene-specific 6-carboxyfluorescin (FAM)-carboxyltetramethyl-rhodamine (TAMRA)labelled Assay-on-Demand C20orf3-specific probe (Applied Biosystems, Forster City, CA, USA) and $25 \mu 1$ of the 2x PCR MasterMix (Roche Diagnostics, Manheim, Germany) diluted to a final volume of $50 \mu \mathrm{l}$ with $\mathrm{H}_{2} \mathrm{O}$. Real-Time PCR was performed in duplicates using an ABI PRISM 7000 Cycler (Applied Biosystems, Forster City, CA, USA). C20orf3 values were normalized to $18 \mathrm{~S}$ or GAPDH as endogenous control using an Assay-on-Demand 18S- or GAPDH-specific probes (Applied Biosystems).

\section{TaqMan SNP genotyping assay}

Isolated genomic DNA (1-20 ng) was diluted in 11.25 $\mu 1 \mathrm{H}_{2} \mathrm{O}$ and combined with $12.5 \mu 1$ TaqMan universal PCR Master Mix (2x) (Applied Biosystems) and $1.25 \mu 1$ of 20x working stock of C20orf3 SNP genotyping assay. This was purchased from Applied Biosystems (C-25652369_10 and C-61038612_10) for the polymorphic site of aa 282 
(rs28364786) and aa 374 (rs35097515) according to NCBI dbSNP rs\# cluster identification. Each genotyping assay set contains a probe labelled with VIC specific for one allele and a probe labelled with FAM specific for the second allele. Detailed information is provided in the manufacturer's instructions. The reaction mix was set up in a 96 well optical plate and PCR cycling and allele discrimination analysis was carried out at an ABI Prism 7000 cycler using the ABI Prism 7000 SDS software.

\section{Ion exchange chromatography}

The Ni-NTA His-Bind ${ }^{\mathbb{B}}$ Resin purified insect cell derived protein $(1 \mathrm{ml})$ was applied on to a fast-protein liquid chromatography (FPLC) system (ÄKTA Explorer; Amersham Biosciences, Buckinghamshire, UK). Ion exchange chromatography was performed on a $Q$ Sepharose column (HiTrap FF $1 \mathrm{ml}$ ) using the Buffer Prep program AIEX. The separation was geared by a specific program chosen in accordance with the column using Unicorn software. The flow rate was $1 \mathrm{ml} / \mathrm{min}$. $500 \mu \mathrm{l}$ fractions were collected and the appropriate peak has been used for further analysis and testing. All chromatographic media were purchased from Amersham Biosciences.

\section{ELISA measurement}

Reacti-Bind $^{\mathrm{TM}}$ goat anti-mouse coated plates (Pierce) were incubated over night at $4{ }^{\circ} \mathrm{C}$ with polyclonal mouse anti C20orf3 diluted in tissue culture media (1/400). After a wash with PBS biological fluid or a serial dilution of human recombinant C20orf3 as standard (100 $\mu \mathrm{l}$ each) were incubated for $2 \mathrm{~h}$ at room temperature under constant shaking. Bound antigen was detected with rabbit anti human $\mathrm{C} 20$ orf3 $\mathrm{Ab}$ (1/4000, $90 \mathrm{~min})$ followed by peroxidase-labeled goat anti-rabbit $\mathrm{Ab}$ (1/6000 dilution, $90 \mathrm{~min}$; Dako). Following each incubation step the plate was washed (3x) with PBS/0.1\% Tween 20 (BioRad) in the ELX Auto strip Washer (Biotec Instruments, Winooski, VT, USA). The ELISA was developed using tetramethylbencidine dihydrochloride two-component peroxidase substrate solution (Kirkegaard \& Perry, Gaitersburg, MD, USA). After stopping the reaction with $1 \mathrm{M} \mathrm{H}_{3} \mathrm{PO}_{4}$ the absorbance was quantitated at $450 \mathrm{~nm}$ using a Powerwave ELISA reader (Biotec Instruments), and concentrations were calculated according to the standard curve with human recombinant C20orf3.

\section{Immunoblot analysis}

Healthy kidney tissue obtained from tumour nephrectomy, healthy liver from tumour metastasektomie and placenta tissues were cut into small pieces which were homogenized using the Sample Grinding Kit (Amersham Biosciences, Piscataway, NJ, USA) and Weinberg lysis buffer containing $50 \mathrm{mM}$ Hepes $\mathrm{pH} 7.0,0.5 \%$ Nonidet P-40, $250 \mathrm{mM} \mathrm{NaCl}, 5 \mathrm{mM}$ EDTA and protease inhibitors (cComplete Mini, Roche, Mannheim, Germany). Clarified samples were either frozen in aliquots or used immediately. Cell lines Hek 293, SH-SY5Y and Hep G2 were grown under standard culture conditions in RPMI 1640 supplemented with $10 \%$ fetal bovine serum at $37{ }^{\circ} \mathrm{C}, 5 \% \mathrm{CO}_{2}$ and $95 \%$ humidified air.

Thirty $\mu \mathrm{g}$ protein aliquots were loaded onto $12 \%$ SDS-PAGE, which were run at 200 V using Tris-glycine running buffer. A semidry blotting device was used to electrophoretically transfer the protein onto nitrocellulose. The blotted membrane was blocked (40 min) with $2 \%$ skim milk/PBS. Antigen detection was performed (overnight, constant shaking at $4{ }^{\circ} \mathrm{C}$ ) with the polyclonal mouse/rabbit anti-C20orf3 antibody (1/1500). Peroxidase-conjugated goat anti-mouse/rabbit antibody (1/3000) was used for detection of antibody binding sites (Dako Glostrup, Denmark). Each incubation step was followed by two washes with PBS containing $0.1 \%$ Tween 20 for $10 \mathrm{~min}$. Binding site visualization was 
carried out by $\mathrm{BM}$ chemiluminescence reagent and electronic images were recorded using Lumi-Imager F1 (Roche Molecular Biochemicals).

\section{Immunostaining}

Four $\mu \mathrm{m}$ kidney, liver and pancreas tissue cryosections were air dried and fixed with $3 \%$ paraformaldehyde/PBS ( $3 \mathrm{~min}$ ) followed by PBS washing. Mouse monoclonal antibody 56 (mAb56) and control (mouse Ig) was applied on the sections together with (1/3000 in PBS) rabbit anti SCGN [24,25] for human pancreas and incubated overnight at $4{ }^{\circ} \mathrm{C}$. After $10 \mathrm{~min}$ washing with PBS under constant stirring Alexa Fluor 488 conjugated donkey anti-mouse or goat anti-rabbit (1/200/PBS, Molecular Probes, Eugene), and Rhodamine (TRITC)-conjugated AffiniPure $\mathrm{F}(\mathrm{ab})_{2}$ labelled Goat anti-mouse $(\mathrm{H}+\mathrm{L})$ IgG (Accurate Chemical \& Scientific Corporation, Westbury, NY, USA) was incubated for $45 \mathrm{~min}$ at room temperature. Following a 10 min washing step, slides were mounted using Vectashield Mounting Medium with DAPI (Vector, Burlingame, CA, USA) and covered with a cover slip. Confocal images were recorded using a Zeiss Axiovert confocal microscope and further processed using Adobe Photoshop 6.0.

\section{In silico analysis}

In order to identify the hydropathy of the C20orf3 gene product, we have entered the gene sequence into the bioinformatic software SeqVu 1.0 (The Garvan Institute of Medical Research, Australia). For transmembrane and signal peptide determination Signal P 3.0 Server (Technical University of Denmark) and the PHD prediction server http://cubic.bioc.columbia.edu/ have been used. The domain search was performed at ProDom http://protein.toulouse.inra.fr/prodom.html. The 3D structure image of C20orf3 was generated using Cn3D 4.1 software. This program has been obtained from NCBI together with the coordinates of the well known 3D structure of plant strictosidine synthase which has been taken as a template for alignment with C20orf3 protein and definition of its coordinates. For sequence alignment Clustal X2 (Conway Institute, UCD, Dublin) was used.

\section{FACS Analysis}

Peripheral blood cells were incubated with red cell ammonium chloride-based haemolysis-buffer solution on ice $(20 \mathrm{~min})$. For cell surface staining aliquots of washed leukocytes were incubated with mAb56-FITC and control for $45 \mathrm{~min}$ on ice including Beriglobin (Aventis Behring GmbH, Vienna, Austria) for blocking Fc binding. After two washing steps fluorescence measurement was carried out on a Becton Dickinson (BD) FACS Calibur by gating specifically for lymphocytes, granulocytes and monocytes.

Logarithmically growing Hep G2 hepatoma cells were obtained either by trypsinization or detachment from the flask by vigorous pipetting. Antibody staining was carried out with mAb56-FITC on ice. Cell surface expression was evaluated on the FACS Calibur (BD).

FACS dual colour analysis was performed using either co-staining of mononuclear cells with the anti-HLA-DR PerCP-specific Ab (BD) or the anti-human CD14-PE-specific Ab (BD) and FITC-conjugated mAb56 including Beriglobin. Dual colour profiles were recorded on the FACS Canto and analysed with FACSDiva Version 6.0 (BD) software. FITCconjugated $\mathrm{mAb} 56$ was diluted in all experiments $1 / 100$ in Beriglobin $(1 \mathrm{mg} / \mathrm{ml})$.

\section{Sucrose gradient}

Rin-5F (ATCC, CRL-2058) and Hep G2 cells were cultured in $75-\mathrm{cm}^{2}$ tissue culture flasks. At $75 \%$ confluence, both were washed twice with ice-cold PBS and then scraped into $2.5 \mathrm{ml}$ of ice-cold homogenization buffer $(250 \mathrm{mM}$ sucrose and $3 \mathrm{mM}$ imidazole, $\mathrm{pH} 7.4)$ supplemented with protease inhibitors $(10 \mathrm{~g} / \mathrm{ml}$ aprotinin, $1 \mathrm{~g} / \mathrm{ml}$ pepstatin, $10 \mathrm{~g} / \mathrm{ml}$ leupeptin, 
and $0.8 \mathrm{mM}$ pefabloc). The cell suspension was then passed four times through a 22-gauge needle. After centrifugation $\left(2200 \mathrm{~g}, 10 \mathrm{~min}, 4^{\circ} \mathrm{C}\right)$, the post-nuclear supernatant was overlaid on a discontinuous sucrose gradient (50\% and $20 \%$, respectively) in $14 \times 95-\mathrm{mm}$ polyallomer centrifuge tubes (Beckman Instruments, Palo Alto, CA, USA) and centrifuged at $70000 \mathrm{~g}$ for $2 \mathrm{~h}$ at $4{ }^{\circ} \mathrm{C}$ in the SW40 TI rotor of an ultracentrifuge (model L-80, Beckman). The resultant density equilibrium was then fractionated using a peristaltic pump. Starting at the bottom, we collected 21 aliquots. The fractions were subjected to immunoblot analysis for C20orf3 geneproduct, $25-\mathrm{kDa}$ synaptosomal-associated protein (SNAP-25) or NEM-sensitive factor (NSF) and arlyesterase detection assays with $\beta$-naphtyl acetate and phenyl acetate.

\section{Detection of arylesterase activity Zymography}

Samples were loaded onto a 10\% PAGE gel omitting ionic detergents. The gel was run at $200 \mathrm{~V}$ using TRIS/Glycin. Enzyme detection was performed as indicated earlier [8] by immerging the gel in a solution of $\beta$-naphthyl acetate.

The enzyme substrate solution consisted of $80 \mathrm{mg} \beta$-naphthyl acetate and $40 \mathrm{mg}$ Fast Blue BB salt (both from Sigma) dissolved in $20 \mathrm{ml}$ ethylene glycol monomethyl ether. The resultant solution was further diluted to $50 \mathrm{ml} 20 \mathrm{mM}$ Tris buffer $\mathrm{pH} 8.0$ including $5 \mathrm{mM}$ $\mathrm{CaCl}_{2}$.

\section{Arylesterase activity with phenyl acetate}

Measurement of arylesterase activity with phenyl acetate was performed in $20 \mathrm{mM}$ Tris-HCl, $\mathrm{pH} 8.0$ and $1 \mathrm{mM} \mathrm{CaCl}$ (for $\mathrm{Ca}^{++}$free conditions: $\mathrm{CaCl}_{2}$ was omitted in presence of $5 \mathrm{mM}$ EDTA) by monitoring the extinction value at $270 \mathrm{~nm}$ (Ultrospec 3000, Pharmacia Biotech) for three minutes as essentially described by Connelley [26]. The enzymatic activity of each fraction was given in $U$ defined as hydrolysis of $1 \mu$ mol phenyl acetate using a molar extinction coefficient of $1310 \mathrm{M}^{-1} \mathrm{~cm}^{-1}$ for phenyl acetate.

\section{Statistical Analysis}

Statistical analysis was calculated using the Student's t-test to compare means of three or four experiments. Results represent mean \pm SD out of 3 to 4 experiments. Values are considered as significantly different, when $\mathrm{p}<0.05$. 


\section{RESULTS}

\section{Cloning and C20orf3-transcript characterization}

Inspired by the fact of high expression levels at various tissues deduced from array based expression screens, we cloned the open reading frame 3 encoded at human chromosome 20 (C20orf3). After choosing specific primers, cDNA of the coding sequence was amplified by PCR using a proof reading enzyme. The resultant product was ligated into a replication plasmid and sequenced.

In silico analysis confirmed an open reading frame coding for a protein of 416 aas (Figure 1). It consists of an N-terminal cytosolic tail (39 aa) followed by a single transmembrane-domain (40-61 aas) and a cell surface location of the main part of the protein (62-416 aas). Two cysteins with a high confidence level for intra- and intermolecular disulfide bonding are located at the anterior part (aas 140 and 149) and one additional cystein is located at the C-terminal end (aa 409). Two potential glycosylation sites were identified at amino acid 160 as well as 196.

Additionally, we found multiple similarities with the paraoxonase (PON) family of detoxifying enzymes. Firstly, PON2 and C20orf3 share some degree of identity at their primary structure (Figure 2) together with plant stictosidine syntase (SS) and DFPase. Secondly, both proteins are characterized by an N-terminally located single transmembrane domain. Thirdly, the PON family members and the C20orf3 gene share a 9 exon structure, which directs towards a common ontogenetic origin.

Interestingly, a review of C20orf3-specific GEO Profiles at NCBI showed that the gene undergoes a time dependent down-regulation upon exposing serum starved fibroblasts to serum (GDS85/6772) and that oxidized LDL induces an up-regulation of this gene in retinal epithelial cells (GDS2307/228309_at). This indicates a metabolic regulation resembling that of PON family members.

Further comparative sequence analysis and conserved domain search revealed similarities between plant SS and C20orf3. This degree of similarity enabled tertiary structure modelling, using Cn3D 4.1 software which also provided similar coordinates for the Cterminal C20orf3 protein and the well known six bladed $\beta$-propeller structure of SS (Supplement A).

\section{Recombinant protein production and antibody generation}

In order to obtain further information on the properties of the C20orf3 gene product, we focused on its recombinant expression. In an initial attempt the coding sequence of aas 45416 was cloned into the expression vector pDEST ${ }^{\mathrm{TM}} 15$. Notably, the protein had to be recovered from E.coli inclusion bodies, indicating its insolubility. The Superose chromatographically purified protein was used for mAb production. Because of its insolubility, an additional transcript omitting the hydrophobic transmembrane- and the cytosolic domain (aas 58-416) was recombinantly expressed using the pGEX-1 $\lambda \mathrm{T}$ expression vector. This resulted in complete solubility of the GST-purified protein named GST-C20orf3748 , which could be used in further ELISA based antibody screening methods.

Using ELISA screening, we selected one antibody (mAb56) specifically recognizing the cell surface domain of the C20orf3 gene product. Furthermore, the GST-purified protein was used for mouse- and rabbit polyclonal antibody generation. Additionally, a polyclonal rabbit antibody was generated using an N-terminal-, cytosolic domain-specific synthetic peptide (as indicated in the supplementary method section).

Aiming at the recombinant expression of a more physiological C20orf3 variant, we changed the expression system towards a eukaryote organism. For this purpose, the insect cell lines Sf9 and High Five were transfected with a baculovirus based system, using the pDEST TM10 baculo competent Gateway vector encoding the aas 45-416 of the C20orf3 gene. 
This sequence only lacked the cytosolic domain, but included a significant part of the transmembrane and full length cell surface domain, resulting in a $46 \mathrm{kDa}$ protein (Figure 3). The N-terminal His-Tag enabled us to purify the protein using Ni-NTA His-Bind ${ }^{\circledR}$ Resin from Sf9 and High Five cell lysates. Further purification was performed by ion exchange chromatography. This resulted in a highly purified protein, which was soluble in buffer consisting of $300 \mathrm{mM} \mathrm{NaCl}$ and $50 \mathrm{mM}$ sodium phosphate $\mathrm{pH}$ 7.4.

\section{Tissue expression pattern of the C20orf3 transcript}

We investigated the tissue expression pattern of the C20orf3 transcript using multiple tissue Northern blots and a C20orf3-specific cDNA probe. A dominant size transcript of about $2.4 \mathrm{~kb}$ was ubiquitously found in adult as well as in embryonic tissues (Figure 4). Interestingly, we found differences in the distribution when comparing the maturation status of the tissues. In adult tissue, highest expression was found in the liver, the placenta and the heart. In embryonic tissue, highest expression levels were found in the liver and the kidney.

To confirm and to extend the Northern analysis, RT-qPCR was carried out on human placenta, kidney and liver tissues. As in vitro models, the human embryonic kidney cell line HEK 293, the SH-SY5Y neuroblastoma cell line and the human hepatoma cell line Hep G2 were included in the analysis. In line with the Northern blot results, highest expression levels were found in liver followed by the hepatoma cell line Hep G2, with lower expression levels in kidney derived tissue and in the embryonic kidney cell line HEK 293 (Figure 5A).

\section{Immunoblot analysis}

To identify C20orf3 protein variants, we tested various cell lines and ex vivo tissues by immunoblotting using the polyclonal rabbit and mouse antibodies generated against the cell surface domain (aas 58-416), respectively. In addition to the full size protein of $50 \mathrm{kDa}$, the cell surface-specific antibody detected two protein bands of 30 and $32 \mathrm{kDa}$ (Figure 5B). It has to be stressed that the quantity as well as the ratio of the individual bands varied, depending on the cell lines. The $30 \mathrm{kDa}$ band increased in repeated freeze-thaws, suggesting a degradation product. An additional $52 \mathrm{kDa}$ size variant was observed in Hep G2 and SHSY5Y.

The cytosolic domain-specific antibody exhibited immunoreactivity against the 32 $\mathrm{kDa}$ and $50 \mathrm{kDa}$ protein, confirming an intact $\mathrm{N}$-terminus within these variants. In contrast, no detection of the $30 \mathrm{kDa}$ moiety was found with the cytosolic domain-specific antibody (data not shown).

Thirty $\mu \mathrm{g}$ of total protein derived from ex vivo tissue (placenta, kidney and liver) were loaded onto SDS-PAGE gel, blotet onto nitrocellulose and developed with polyclonal mouse anti cell surface domain-specific antibody. This revealed the dominant $50 \mathrm{kDa}$ size variant with a degradation product at small peptide size. Its high expression in human liver and placenta (Figure $5 \mathrm{C}$ ) confirmed the mRNA results.

To identify the individual cell types expressing the C20orf3 gene product, confocal immunofluorescence and immunohistochemical analysis of renal, hepatic and pancreatic tissue sections were performed. For the immunohistochemical analysis (data not shown) we used the polyclonal, N-terminal- and cell surface part-specific rabbit antibody. For immunofluorescence analysis, we used the newly generated mAb56. Interestingly, this revealed a highly characteristic expression pattern of C20orf3 in these organs. Within the kidneys, we found strong immunostaining of the glomerula, albeit with varying staining intensities (Figure 6A). The epithelial cells of distinct tubuli were also characterized by a marked staining (Figure 6B). Additionally, expression of the protein was found in endothelial cells and smooth muscle cells of kidney vascular structures (Figure 6C). Strong staining intensities of human liver (Figure 6D) confirmed RT-qPCR and immunoblotting results. Staining of human pancreatic tissue revealed high expression of the protein at the islet of 
Langerhans. The endocrine part of the pancreas was identified by parallel immunostaining for the islet-specific SCGN gene product (green) and for the C20orf3 gene product (red) and subsequent dual colour confocal microscopy (Figure 6E).

\section{Cell surface localization of the C20orf3 gene product}

To confirm the cell surface localization of the C20orf3 gene product, which was implicated by the comparative sequence analysis, FACS measurement of dispersed Hep G2 cells using the newly prepared mAb56-FITC was performed (Figure 7A). Hep G2 cells were either detached with trypsin or mechanically (vigorous pipetting). As expected, Hep G2 cells exhibited high surface staining intensities. Remarkably, trypsin-treatment resulted in a marked reduction of the immunostaining intensities, indicating loss of the cell surface part due to C20orf3 trypsin-fragmentation. In analogy to PON family members, we additionally found high C20orf3 immunostaining intensities of monocytes, which have been identified by costaining for CD14 (Figure 7B). In contrast, granulocytes and lymphocytes did not show any mAb56-specific cell surface staining.

\section{Subcellular localisation of the protein}

In our intention to identify the subcellular distribution of the C20orf3 protein variants in more detail, we performed a sucrose-gradient fractionation of Rin-5F cells. The individual fractions were subsequently analysed by immunoblotting. Using the well established membrane marker protein SNAP-25 we identified that the high molecular weight C20orf3 protein appeared in the heavy membrane fractions (Figure 8Aa). Only a minor quantity of the smaller variant and some degradation products were also detected in these fractions. In addition the $32 \mathrm{kDa}$ variant was found within the cytosolic fractions, indicated by absence of SNAP-25 (Figure 8Ab). This demonstrates different intracellular compartmentalization of these variants.

With the intention to compare the subcellular location pattern of C20orf3 in Rin-5F cells with that of a human cell line, sucrose gradient centrifugation of the human hepatoma cell line Hep G2 was performed. Interestingly we found the full-length protein in membrane fractions (Figure 8Ba). The $32 \mathrm{kDa}$-variant was found in the membrane fractions at scant quantity. In these experiments, the SNARE family member NEM-sensitive factor (NSF) was used as membrane marker.

\section{Enzymatic activity of the C20orf3 gene product containing fractions}

To screen for an enzymatic activity of the C20orf3 gene product, we performed arylesterase staining of the individual fractions with $\beta$-naphthyl acetate obtained by sucrose gradient cell fractionation of Rin-5F (Figure 8Ac) and Hep G2 (Figure 8Bb) cells, subsequent PAGE and zymography, This revealed arylesterase activity in samples which tested positive for the C20orf3 gene product in parallel immunoblot analysis.

The same fractions were evaluated using spectrophotometric analysis for arylesterase activity with phenyl acetate (Figure 8Ad, 8Bc). The fractions containing C20orf3 gene product exhibited a high arylesterase activity. Under $\mathrm{Ca}^{++}$chelated conditions enzyme activity was reduced by about 1/3 (Figure 8Ae, 8Bd).

\section{Expression regulation of the C20orf3 gene product}

In order to elucidate in further detail the C20orf3 gene expression regulation we cloned the gene promoter $(1081 \mathrm{bp})$ in front of the Ranilla luciferase gene using the pMLuc 3 reporter vector. This region includes $936 \mathrm{bp}$ upstream of the defined transcription start site and consists of 62 well defined transcription regulatory elements (GATA1, 2 and 3, Sp1, AP1, NFkB, Pbx1, Ik-2 and others). The reporter gene assay was performed in Hek 293 cells $24 \mathrm{~h}$ after stimulation with human serum. Under basal conditions, the Hek 293 cells exhibited a 
considerable expression efficacy for the tested sequence when compared with the vector omitting the promoter insert (background expression $<10 \%$ ). Luciferase light units were normalised to 10000 cells. Hek 293 cell exposure to human serum resulted in a marked and significant reduction $(42 \pm 11 \% ; \mathrm{p}<0.003 ; \mathrm{n}=4)$ of $\mathrm{C} 20$ orf3 transcription when compared to control (without serum, WO).

Additionally, we performed FACS analysis using mAb56 and qPCR experiments comparing the C20orf3 expression in un-stimulated and serum-stimulated Hek 293 cells. In line with the luciferase reporter expression analysis, the serum treatment resulted in a marked decrease of C20orf3 cell surface detection $(56 \pm 21 \% ; \mathrm{p}<0.01 ; \mathrm{n}=4)$ as well as in a downregulation of the $\mathrm{C} 20$ orf3 gene expression $(80 \pm 6 \%$; $<0.0003 ; n=3)$.

\section{Genotyping}

SNP-genotyping using specifically purchased Taq-Man probes to evaluate polymorphic amino acids 282 and 374 we identified homozygocity for $282 \mathrm{R}$ and $374 \mathrm{R}$ in 100 individuals originating from middle European population.

\section{ELISA measurement of the C20orf3 transcript in different biological fluids}

In order to elucidate if the protein is secreted or parts of it can be shad into different body fluids we performed ELISA using serum, pleural effusions and urine. The protein concentration in serum was below the detection limit of our ELISA ( $35 \mathrm{pg} / \mathrm{ml})$. Surprisingly, the protein was found in urine of some individuals and could be measured in supernatant of thrombin treated Hep-G2 cells $(\sim 60 \mathrm{pg} / \mathrm{ml})$. 


\section{DISCUSSION}

In this study we present the characterisation of the C20orf3 gene product, its expression topology as well as potential functional aspects. According to structural characteristics, C20orf3 is related to PONs, especially to PON2.

Structural analysis revealed that C20orf3 contains a hydrophobic region at the Nterminus (aas 40 to 61), which is typical for transmembranous regions. According to in silico analysis, the $\mathrm{C} 20$ orf3 gene product represents a $46 \mathrm{kDa}$ protein, which consists of 416 aas. However, our immunoblot data showed a protein presenting with two bands of about 50 and $52 \mathrm{kDa}$ in cell lines. This is in analogy to PON1 and was attributed to glycosylation [27]. In this context, the glycosylation sites at aas 160 and 196 exhibited by the C20orf3 sequence seem of interest. The fact that the $\mathrm{C} 20$ orf3 protein is prone to glycosylation was confirmed recently by another research group, who found peptides out of this protein in the course of NGlykoproteom analysis by hydrazide chemistry [28]. This indicates that the differences between the expected molecular weight and that observed in the immunoblot analysis might be due to glycosylation. Interestingly we found two additional bands in our immunoblots of 30 and $32 \mathrm{kDa}$. The detection of the $32 \mathrm{kDa}$ band with the N-Terminal peptide specific antibody indicates that this variant contains the cytosolic domain. Looking at the ESTDatabase we found splice variants lacking exons 3, 4 and 5 (BI117692). This results in a truncated C20orf3 variant containing the cytosolic part and finds parallels in splice variants described for the PON2 enzyme [5]. The smaller protein band of about $30 \mathrm{kDa}$ is not detected by the cytosolic-domain-specific antibody and increased after repeated freeze-thaws of the cell lysates, which supports the assumption of representing a degradation product. Small peptide size degradation products were detected in all ex vivo tissue lysates.

Tests for C20orf3 gene regulation point towards serum factors influencing its expression. This is underlined by the fact that the protein surface expression is reduced upon exposure to human serum using the embryonic kidney cell line. Although expression suppression of C20orf3 after serum exposure seems to be the main contributor to this phenomenon, internalization of the protein upon ligand or substrate association might also play a role. This is underlined by the finding, that the C20orf3 suppression detected at the mRNA level was less intense than that at the protein level.

It represented one of our goals to define a substrate for this molecule. It is important to note that in the mouse this protein has been identified as adipocyte plasma membraneassociated protein and has been shown in 3T3-L1 cells induced to differentiate towards adipocytes [29]. Although these important data give evidence that in rodents the protein might have some functional relevance in adipocyte differentiation, our data of ubiquitous expression in humans demonstrate a functional relevance beyond adipose tissue, most strikingly in the liver and the central nervous system as well as the kidney and in blood vessels.

Although a detailed functional analysis of the C20orf3 gene product is still missing, high aryl esterase activity was found in the C20orf3 gene product containing cell fractions. Furthermore, the sequence homology with PON family members within the functionally active protein parts points towards an enzymatic activity of this protein. The definition of its substrate seems of particular interest as the protein is expressed in organs involved in detoxification processes. It is additionally present at the surface of monocytes and of endothelial cells. Moreover, C20orf3 gene expression is influenced by human serum. All these characteristics are in line with human PON family members [30,31], which are known to be involved in antioxidant processes $[32,6,10]$. Oxidative radicals represent important contributors to atherosclerosis development. There are several indicators for C20orf3 involvement in anti-oxidative processes. The results of a GEO profile review revealed C20orf3 transcript up-regulation in skeletal muscle of children suffering from Duchenne's muscular dystrophy. This disease due to impaired dystrophin function is thought to be the 
result of calcium overflow and oxidative radical production finally leading to muscle cell death. Furthermore, retinal epithelial cells respond with up-regulation of the gene following treatment with oxidized LDL (GEO Profile, GDS2307). Additionally, the demonstrated under-expression in placentas from patients with pre-eclampsia might also point in this direction [33].

We want to conclude of having identified the protein encoded by the C20orf 3 and its protein variants as well as the sites of expression in humans. Due to sequence similarities and parallels of the expression pattern with PON family members, we hypothesize that the C20orf3 gene product represents a novel member of this enzyme family detected at the cellular level. Its characteristic renal, hepatic and endothelial cell expression pattern points towards important biological functions most likely basing on its substrate specificity or ligand interaction. 


\section{SUPPLEMENT:}

\section{RT-PCR and PCR amplification of C20orf3}

After pre-treatment with DNAase I (15 min, room temperature), $1 \mu \mathrm{g}$ of total RNA was subjected to reverse transcription $\left(1 \mathrm{~h}, 40^{\circ} \mathrm{C}\right)$ using Superscript II (Invitrogen, Carlsbad, CA, USA). cDNA synthesis was stopped by heating $\left(15 \mathrm{~min}, 65^{\circ} \mathrm{C}\right.$ ). Primers (fw: 5'-ATGAGCGAGGCGGACGG-3'; rev: 5'-TATCTGGGAGGGCTAAACAGC-3') were designed to amplify the coding part of the human gene (1248 bp). PCR was performed using the Expand ${ }^{\mathrm{TM}}$ High Fidelity PCR System (Boehringer Mannheim, Germany) at the following cycling parameters ( $35 \mathrm{cycles}): 94{ }^{\circ} \mathrm{C}$ for denaturation $(30 \mathrm{sec}), 62{ }^{\circ} \mathrm{C}$ for annealing $(30 \mathrm{sec})$ and $72{ }^{\circ} \mathrm{C}$ synthesis $(30 \mathrm{sec})$ with a final extension period of $7 \mathrm{~min}$ at $72{ }^{\circ} \mathrm{C}$.

\section{Cloning of the human C20orf3}

Overhangs were added to the gel-purified PCR product using Taq polymerase (Invitrogen). The resultant inserts were ligated into the pGEM $^{\circledR}$-T-easy vector using T4 ligase (both from Promega) according to the manufacturer's instructions. Ligated plasmids were transformed into MAX Efficiency DH5 $\alpha^{\circledR}$ Competent bacteria (Invitrogen) by the heat shock method. Transformants were plated onto LB/Amp/Xgal plates and white clones were further screened by colony PCR using the above indicated gene-specific primers. Colonies containing the right insert were grown over night in LB/Amp agar plates and isolated using the Plasmid Mini Kit (Qiagen, Hilden, Germany). Isolated plasmids were subjected to restriction enzyme digest and DNA sequencing.

\section{Directional cloning of the human C20orf3 protein using Gateway technology}

Four nucleotides (CCAC) were added at the 5 end of the coding region in front of the start codon. For this purpose a second forward primer (5'-CACCATGAGCGAGGCGGACGG-3') had to be chosen. The PCR product was obtained as described above using the Expand ${ }^{\mathrm{TM}}$ High Fidelity PCR System. The amplification product was cloned into $p E N T R / D-T O P O$ vector. The ligated vector was transformed into MAX Efficiency DH5 $\alpha^{\circledR}$ Competent bacteria, which were plated onto LB/Kan plates. Colonies with the correct orientation (identified by PCR) were chosen for amplification and plasmids were purified using the Qiagen Plasmid Mini Kit.

\section{Transfer of C20orf3 gene from pENTR/D-TOPO to pcDNA-DEST plasmids}

The clonase reaction was performed as indicated in the product manual (Invitrogen). In brief: $300 \mathrm{ng}$ of pENTR/D-TOPO and $300 \mathrm{ng}$ of pcDNA-DEST 15 was combined and incubated with clonase for one hour at $25{ }^{\circ} \mathrm{C}$ followed by transformation into MAX Efficiency DH5 $\alpha^{\circledR}$ competent bacteria and subsequent selection on LB/Amp agarose plates.

\section{Baculovirus preparation and insect cell culture Preparation of recombinant Baculo virus}

The cDNA of C20orf3 coding for aas 16 to 416 was cloned into the Baculovirus compatible pDEST TM10 expression vector (Invitrogen). After insert verification the Bac-to$\mathrm{Bac}^{\circledR}$ Baculovirus expression system was chosen following the manufacturers instructions (Invitrogen, 10359, version D). In brief: MAX Efficiency ${ }^{\circledR}$ DH10Bac ${ }^{\mathrm{TM}}$ competent cells containing wild type bacmid and helper plasmid were transformed with pDEST ${ }^{\mathrm{TM}} 10$ containing the $\mathrm{C} 20$ orf3 using a $45 \mathrm{sec}$ heat shock at $42{ }^{\circ} \mathrm{C}$ followed by a $4 \mathrm{~h}$ incubation at $37{ }^{\circ} \mathrm{C}$ under constant rotation ( $225 \mathrm{rpm}$ ). Recombinants were selected on $7 \mu \mathrm{g} / \mathrm{ml}$ gentamycin, $10 \mu \mathrm{g} / \mathrm{ml}$ tetracycline, $50 \mu \mathrm{g} / \mathrm{ml}$ kanamycin, $300 \mu \mathrm{g} / \mathrm{ml} \mathrm{S}-\mathrm{Gal}, 30 \mu \mathrm{g} / \mathrm{ml} \mathrm{IPTG/LB}$ agar plates. White colonies were selected and tested by colony PCR after $48 \mathrm{~h}$ incubation at $37{ }^{\circ} \mathrm{C}$ and inoculated in LB containing the same combination of antibiotics as described above. 
Recombinant bacmid was purified under standard conditions such as described at the manufacturer's test manual.

\section{Sf9 and High Five insect cell transfection}

Cellfectin-bacmid transfection mixture was prepared by co-incubation of Cellfectin ${ }^{\circledR}$ Reagent (Invitrogen, 10362-010) and bacmid DNA in $200 \mu$ l unsupplemented Grace's Insect Medium (Invitrogen, 11595-030) for $20 \mathrm{~min}$ at room temperature. Logarithmically growing Sf9 and High Five cells were exposed to transfection mixture for $4 \mathrm{~h}$ which was replaced then by Insect-Xpress (BioWhittaker, 12-730F) for protein expression and Baculovirus collection. For maintaining virus titer stability the resultant fluid was supplemented with $2 \%$ calf serum (final concentration). Verification of protein translation and expression in insect cells was performed using the anti-His Tag mAb clone HIS.H8 (Upstate, Tamecula, CA, USA) in immunoblotting techniques on Sf9 and High Five cell lysates.

\section{Purification of Sf9 and High Five cell expressed C20orf3 protein}

Three days after infection with recombinant baculo (\#855) Sf9 or High Five cells were harvested by centrifugation followed by lysis in native lysis buffer $(300 \mathrm{mM} \mathrm{NaCl}, 50 \mathrm{mM}$ sodium phosphate buffer, $\mathrm{pH} 8.0,20 \mathrm{mM}$ imidazole). After a brief sonication with 8 strokes the insoluble material was pelleted in a Beckmann J2-MC centrifuge using the JA 20 rotor at $20000 \mathrm{~g}$ for $15 \mathrm{~min}$ at $4{ }^{\circ} \mathrm{C}$. The supernatant was incubated with pre-equilibrated Ni-NTA His-Bind ${ }^{\circledR}$ Resin (Novagen) for $30 \mathrm{~min}$ at $4{ }^{\circ} \mathrm{C}$ for His-Tag protein binding. The resultant NiNTA His-C20orf3-Resin was washed three times using lysis buffer as described above. Elution of the recombinant protein was carried out using the 1x Ni-NTA Elution Buffer (300 $\mathrm{mM} \mathrm{NaCl} ; 50 \mathrm{mM}$ sodium phosphate buffer, $\mathrm{pH}$ 8.0, $250 \mathrm{mM}$ imidazole).

\section{Purification of inclusion bodies}

Bacteria (BL21) transformed with pDESTTM15-C20orf3-737 vector were grown in TY medium. After induction for four hours at $31^{\circ} \mathrm{C}$ using IPTG $(100 \mu \mathrm{M})$ bacteria were harvested by centrifugation. Lysis was performed in $50 \mathrm{mM}$ Tris-HCl, $\mathrm{pH} 8.0,100 \mathrm{mM} \mathrm{NaCl}$, $5 \mathrm{mM}$ EDTA, $0.1 \% \mathrm{NaN}_{3}$ and $0.1 \mathrm{mM}$ PMSF. After sonication EDTA was chelated by $\mathrm{MgSO}_{4}(10 \mathrm{mM}$ final concentration) and DNase $(0.01 \mathrm{mg} / \mathrm{ml}$ final concentration) and lysozyme $(0.1 \mathrm{mg} / \mathrm{ml}$ final concentration) were added. After $20 \mathrm{~min}$ incubation at room temperature inclusion bodies were pelleted by centrifugation $(14000 \mathrm{~g}, 14 \mathrm{~min})$ in $14 \times 95 \mathrm{~mm}$ polyallomer centrifuge tubes (Beckman Instruments, Palo Alto, CA, USA) in the SW 40 TI rotor (model L-80, Beckman). The resultant inclusion body pellet was resuspended in E.coli lysis buffer as indicated above. Washing of inclusion bodies was repeated 4 times. Purity testing was carried out by SDS-PAGE analysis. Particles were dissolved in $8 \mathrm{M}$ urea for further purification by superose 6 (Pharmacia Biotech AB, Uppsala, Sweden) column chromatography using $6 \mathrm{M}$ urea as mobile phase. The collected fractions containing the fusion protein were selected after SDS-PAGE gel electrophoresis and coomassie blue staining. Pooled fractions were dialysed against PBS, which resulted in precipitation of the fusion protein. The precipitate was collected and frozen at $-80{ }^{\circ} \mathrm{C}$ for further use.

\section{Generation of immunoreagents}

The superose 6 column purified GST-C20orf3-fusion protein was emulsified in Freund s adjuvant and used for immunization of 6-wk-old BALB/c mice by subcutaneous injection. The monoclonal antibody has been generated as previously described [34]. In brief, the spleen of the immunized mouse was removed 4 days after the last immunisation and separated spleen cells were fused with the P3 cells growing in logarithmic phase under standard conditions. Outgrowing clones were screened using a direct ELISA technique. Plates were coated overnight with recombinant protein (aas 58-416). Additionally, all clones were tested in parallel by immunoblot using MiliBlot-MP Membrane Processor (Millipore Corporation, Bedford, MA, USA). 
Poyclonal mouse antibody was generated by three immunizations in two-weeks interval using GST-C20orf3-748 fusion protein. The obtained antiserum was pre-adsorbed to recombinant GST protein covered Glutathion Sepharose 4B. Monospecificity of the resultant $\mathrm{Ab}$ was tested by parallel immunoblotting against GST and the fusion protein. $\mathrm{Ab}$ with absence of GST detection has been used for further procedures.

Polyclonal rabbit antibody was produced by immunizing a six week old rabbit in 22 days interval using the GST-C20orf3-748 fusion protein.

In addition a peptide specific antibody has been generated against the C-terminally KLH conjugated C20orf3-specific peptide GLRQRRPLRPQVVTC (aas 6-19). The antibody directed against the cytosolic part (N-terminus) of the protein was used for characterisation of protein variants containing the cytosolic domain. 


\section{LEGENDS}

Figure 1. cDNA sequence of the human C20orf3 protein and its translation into amino acids. The open reading frame 3 at chromosome 20 consists of 1248 nucleotides which encode a protein of 416 amino acids. This comprises an intracellular part (underlined), a transmembrane domain (bold) and an extra-cellular domain. Polymorphic amino acids at positions 65, 282 and 374 are indicated. Amino acids acting as glycosylation sites (aas 160 and 196) are marked by a cycle.

Figure 2. Similarity between C20orf3, PON 2, SS and DFPase. Similarity between C20orf3 protein sequence and 3 members of six-bladed $\beta$-propeller folded proteins were aligned with software ClustalX2.

Figure 3. Recombinant expression and purification of the C20orf3 gene product in Baculovirus-based High Five cells. C20orf3 was expressed using a Baculovirus-based expression system in High Five insect cells and was subsequently purified by Ni-NTA HisBind $^{\circledR}$ Resin. After PAGE electrophoresis, the protein was detected by a poly-His-specific $\mathrm{mAb}$ (lane 1) and by a rabbit anti cell surface domain-specific Ab (lane 2). For additional purification, the Ni-NTA His-Bind ${ }^{\circledR}$ Resin was subjected to Q Sepharose anion exchange chromatography (lane 3, silver staining).

Figure 4. Multiple tissue Northern analysis of C20orf3 gene expression. Using a 9-exon spanning cDNA probe, we screened embryonic tissues (left), adult tissues (middle) and different compartments of the brain (right). The same blots were re-hybridized using a $\beta$-actin specific probe in order to evaluate the amount of RNA loading.

Figure 5. RT-qPCR and Multiple-western blot analysis of C20orf3 expression. (A) RTqPCR of the cell lines Hek 293, SH-SY5Y and Hep G2 was performed. Additionally, extracts of human placenta, kidney and liver were included in the analysis. (B) The cell lines Hek 239, SH-SY5Y, Hep G2 and (C) human placenta, kidney and liver extracts were subjected to western-blot analysis using the anti-C20orf3 rabbit and mouse antibodies, respectively. Note the three variants detected by the $\mathrm{C} 20$ orf3 gene product specific antibody in cell lines (50/52, 32 and $30 \mathrm{kDa})$. The same blots have been re-probed using the $\beta$-actin-specific mAb for determination of protein loading.

Figure 6. Confocal microscopy of human kidney, human liver and human pancreatic islet cryosections. Kidney and liver sections were stained with the newly generated mouse C20orf3-specific mAb56. Pancreatic islets were co-stained with rabbit anti-secretagogin and mouse anti-C20orf3 mAb56. Nuclear staining was performed with DAPI. (A) Kidney glomerula stained positive for C20orf3 protein (magnification 400x). (B) Distinct kidney tubular epithelia were frequently observed to express the protein (magnification 400x). (C) The C20orf3 gene product was expressed in arterial wall (magnification 400x). (D) Human liver cells stained highly positive for C20orf3 gene product (400x). (E) The C20orf3 gene product was found in pancreatic islet cells (red). The localization of the C20orf3 gene product in the endocrine parts of the pancreas was demonstrated by co-immunostaining for the neuroendocrine-specific marker protein SCGN (green).

Figure 7. FACS analysis of human hepatoma cells (Hep G2) using monoclonal antibody 56 (mAb56). (A) Hep G2 cells stained after trypsinization. The filled curve represents isotype control, the line represents staining with mAb56 after trypsin treatment $(7 \mathrm{~min})$, and the 
hatched line shows Hep G2 cells stained with mAb56 after suspending cells via vigorous pipetting and omitting trypsin treatment. (B) Human peripheral blood monocytes co-stained with FITC labelled mAb56 and PE-A labelled monocyte marker CD14.

Figure 8. Immunoblot analysis of C20orf3 gene product, zymography and arylesterase activity with phenyl-acetate in presence and absence of $\mathbf{C a}^{++}$. The rat insulinoma cell line Rin-5F (A) and Hep-G2 (B) cells were subjected to sucrose gradient cell fractionation. The individual fractions were loaded onto SDS-PAGE gels, transferred onto nitro cellulose and developed by the C20orf3-specific $\mathrm{Ab}$ (Aa, Ba). For identification of the cellular compartment present at the individual fractions, the blot was redeveloped using a SNAP-25specific mAb (for Rin-5F, Ab) and a NSF-specific mAb (for Hep G2, Ba). In parallel the same fractions were loaded onto native-PAGE gels and stained for arylesterase activity using $\beta$-naphthyl acetate as substrate (Ac, Bb). The same fractions of Rin-5F (Ad) and Hep G2 (Bc) cells were tested for arylesterase activity with phenyl acetate using the spectrophotometric method. The same analysis was performed under $\mathrm{Ca}^{++}$chelated conditions (Ae and Bd). Enzyme activity was demonstrated in $\mathrm{U}$ defined as $1 \mu$ mol of phenyl acetate hydrolysed in 3 min. Fraction numbers are indicated at the bottom, molecular weight markers are shown on the left for immunoblot data. 


\section{REFERENCES:}

1 Primo-Parmo, S. L., Sorenson, R. C., Teiber, J. and La Du, B. N. (1996) The human serum paraoxonase/arylesterase gene (PON1) is one member of a multigene family. Genomics 33, 498-507

2 Hassett, C., Richter, R. J., Humbert, R., Chapline, C., Crabb, J. W., Omiecinski, C. J. and Furlong, C. E. (1991) Characterization of cDNA clones encoding rabbit and human serum paraoxonase: the mature protein retains its signal sequence. Biochemistry 30, 10141-10149

3 Ozols, J. (1999) Isolation and complete covalent structure of liver microsomal paraoxonase. Biochem. J. 338 ( Pt 2), 265-272

4 Reddy, S. T., Wadleigh, D. J., Grijalva, V., Ng, C., Hama, S., Gangopadhyay, A., Shih, D. M., Lusis, A. J., Navab, M. and Fogelman, A. M. (2001) Human paraoxonase-3 is an HDL-associated enzyme with biological activity similar to paraoxonase-1 protein but is not regulated by oxidized lipids. Arterioscler. Thromb. Vasc. Biol. 21, 542-547

5 Mochizuki, H., Scherer, S. W., Xi, T., Nickle, D. C., Majer, M., Huizenga, J. J., Tsui, L. C. and Prochazka, M. (1998) Human PON2 gene at 7q21.3: cloning, multiple mRNA forms, and missense polymorphisms in the coding sequence. Gene 213, 149157

6 Ng, C. J., Wadleigh, D. J., Gangopadhyay, A., Hama, S., Grijalva, V. R., Navab, M., Fogelman, A. M. and Reddy, S. T. (2001) Paraoxonase-2 is a ubiquitously expressed protein with antioxidant properties and is capable of preventing cell-mediated oxidative modification of low density lipoprotein. J. Biol. Chem. 276, 44444-44449

7 Billecke, S., Draganov, D., Counsell, R., Stetson, P., Watson, C., Hsu, C. and La Du, B. N. (2000) Human serum paraoxonase (PON1) isozymes Q and R hydrolyze lactones and cyclic carbonate esters. Drug. Metab. Dispos. 28, 1335-1342

8 Draganov, D. I., Teiber, J. F., Speelman, A., Osawa, Y., Sunahara, R. and La Du, B. N. (2005) Human paraoxonases (PON1, PON2, and PON3) are lactonases with overlapping and distinct substrate specificities. J. Lipid Res. 46, 1239-1247

9 Draganov, D. I. and La Du, B. N. (2004) Pharmacogenetics of paraoxonases: a brief review. Naunyn Schmiedebergs Arch. Pharmacol. 369, 78-88

10 Rosenblat, M., Draganov, D., Watson, C. E., Bisgaier, C. L., La Du, B. N. and Aviram, M. (2003) Mouse macrophage paraoxonase 2 activity is increased whereas cellular paraoxonase 3 activity is decreased under oxidative stress. Arterioscler. Thromb. Vasc. Biol. 23, 468-474

11 Mackness, M. I. (1989) 'A'-esterases. Enzymes looking for a role? Biochem. Pharmacol. 38, 385-390

12 Mackness, M. I., Peuchant, E., Dumon, M. F., Walker, C. H. and Clerc, M. (1989) Absence of "A"-esterase activity in the serum of a patient with Tangier disease. Clin. Biochem. 22, 475-478

13 Sorenson, R. C., Bisgaier, C. L., Aviram, M., Hsu, C., Billecke, S. and La Du, B. N. (1999) Human serum Paraoxonase/Arylesterase's retained hydrophobic N-terminal leader sequence associates with HDLs by binding phospholipids : apolipoprotein A-I stabilizes activity. Arterioscler. Thromb. Vasc. Biol. 19, 2214-2225

14 Aviram, M. (1999) Does paraoxonase play a role in susceptibility to cardiovascular disease? Mol. Med. Today 5, 381-386

15 Graham, A., Hassall, D. G., Rafique, S. and Owen, J. S. (1997) Evidence for a paraoxonase-independent inhibition of low-density lipoprotein oxidation by highdensity lipoprotein. Atherosclerosis 135, 193-204 
16 Humbert, R., Adler, D. A., Disteche, C. M., Hassett, C., Omiecinski, C. J. and Furlong, C. E. (1993) The molecular basis of the human serum paraoxonase activity polymorphism. Nat. Genet. 3, 73-76

17 Smolen, A., Eckerson, H. W., Gan, K. N., Hailat, N. and La Du, B. N. (1991) Characteristics of the genetically determined allozymic forms of human serum paraoxonase/arylesterase. Drug Metab. Dispos. 19, 107-112

18 Boright, A. P., Connelly, P. W., Brunt, J. H., Scherer, S. W., Tsui, L. C. and Hegele, R. A. (1998) Genetic variation in paraoxonase-1 and paraoxonase-2 is associated with variation in plasma lipoproteins in Alberta Hutterites. Atherosclerosis 139, 131-136

19 Aharoni, A., Gaidukov, L., Yagur, S., Toker, L., Silman, I. and Tawfik, D. S. (2004) Directed evolution of mammalian paraoxonases PON1 and PON3 for bacterial expression and catalytic specialization. Proc. Natl. Acad. Sci. U S A 101, 482-487

20 Harel, M., Aharoni, A., Gaidukov, L., Brumshtein, B., Khersonsky, O,, Meged, R., Dvir, H., Ravelli, R. B., McCarthy, A., Toker, L., Silman, I., Sussman, J. L. and Tawfik, D. S. (2004) Structure and evolution of the serum paraoxonase family of detoxifying and anti-atherosclerotic enzymes. Nat. Struct. Mol. Biol. 11, 412-419

21 Ma, X., Panjikar, S., Koepke, J., Loris, E. and Stockigt, J. (2006) The structure of Rauvolfia serpentina strictosidine synthase is a novel six-bladed beta-propeller fold in plant proteins. Plant Cell 18, 907-920

22 McCoy, E., Galan, M. C. and O'Connor, S. E. (2006) Substrate specificity of strictosidine synthase. Bioorg. Med. Chem. Lett. 16, 2475-2478

23 Kobayashi, M., Shinohara, M., Sakoh, C., Kataoka, M. and Shimizu, S. (1998) Lactone-ring-cleaving enzyme: genetic analysis, novel RNA editing, and evolutionary implications. Proc. Natl. Acad. Sci. U S A 95, 12787-12792

24 Birkenkamp-Demtroder, K., Wagner, L., Brandt Sorensen, F., Bording Astrup, L., Gartner, W., Scherubl, H., Heine, B., Christiansen, P. and Orntoft, T. F. (2005) Secretagogin is a novel marker for neuroendocrine differentiation. Neuroendocrinology 82, 121-138

25 Gartner, W., Vila, G., Daneva, T., Nabokikh, A., Koc-Saral, F., Ilhan, A., Majdic, O., Luger, A. and Wagner, L. (2007) New functional aspects of the neuroendocrine marker secretagogin based on the characterization of its rat homolog. Am. J. Physiol. Endocrinol. Metab. 293, E347-354

26 Connelly, P. W., Maguire, G. F. and Draganov, D. I. (2004) Separation and quantitative recovery of mouse serum arylesterase and carboxylesterase activity. J. Lipid Res. 45, 561-566

27 Kuo, C. L. and La Du, B. N. (1995) Comparison of purified human and rabbit serum paraoxonases. Drug Metab. Dispos. 23, 935-944

28 Liu, T., Qian, W. J., Gritsenko, M. A., Camp, D. G., 2nd, Monroe, M. E., Moore, R. J. and Smith, R. D. (2005) Human plasma N-glycoproteome analysis by immunoaffinity subtraction, hydrazide chemistry, and mass spectrometry. J. Proteome Res. 4, 20702080

29 Albrektsen, T., Richter, H. E., Clausen, J. T. and Fleckner, J. (2001) Identification of a novel integral plasma membrane protein induced during adipocyte differentiation. Biochem. J. 359, 393-402

30 Kudchodkar, B. J., Lacko, A. G., Dory, L. and Fungwe, T. V. (2000) Dietary fat modulates serum paraoxonase 1 activity in rats. J. Nutr. 130, 2427-2433

31 Rantala, M., Silaste, M. L., Tuominen, A., Kaikkonen, J., Salonen, J. T., Alfthan, G., Aro, A. and Kesaniemi, Y. A. (2002) Dietary modifications and gene polymorphisms alter serum paraoxonase activity in healthy women. J. Nutr. 132, 3012-3017 
32 Aviram, M. and Rosenblat, M. (2004) Paraoxonases 1, 2, and 3, oxidative stress, and macrophage foam cell formation during atherosclerosis development. Free Radic. Biol. Med. 37, 1304-1316

33 Nishizawa, H., Hasegawa, K., Suzuki, M., Kamoshida, S., Kato, T., Saito, K., Tsutsumi, Y., Kurahashi, H. and Udagawa, Y. (2007) The etiological role of allogeneic fetal rejection in pre-eclampsia. Am. J. Reprod. Immunol. 58, 11-20

34 Majdic, O., Liszka, K., Lutz, D. and Knapp, W. (1981) Myeloid differentiation antigen defined by a monoclonal antibody. Blood 58, 1127-1133 
Fig 1

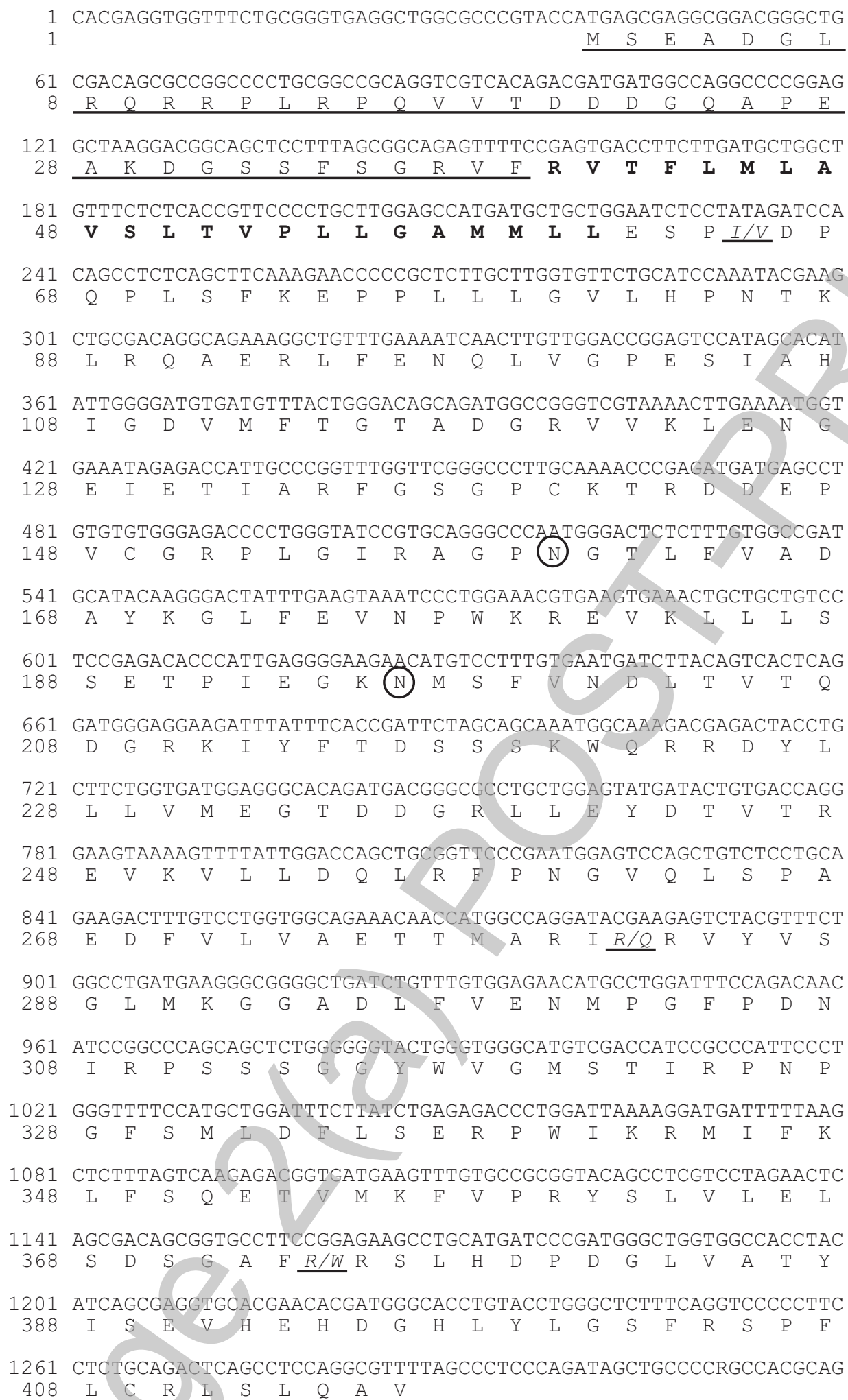




\section{B Biochemical Journal Immediate Publication. Published on 30 May 2008 as manuscript BJ20080503}

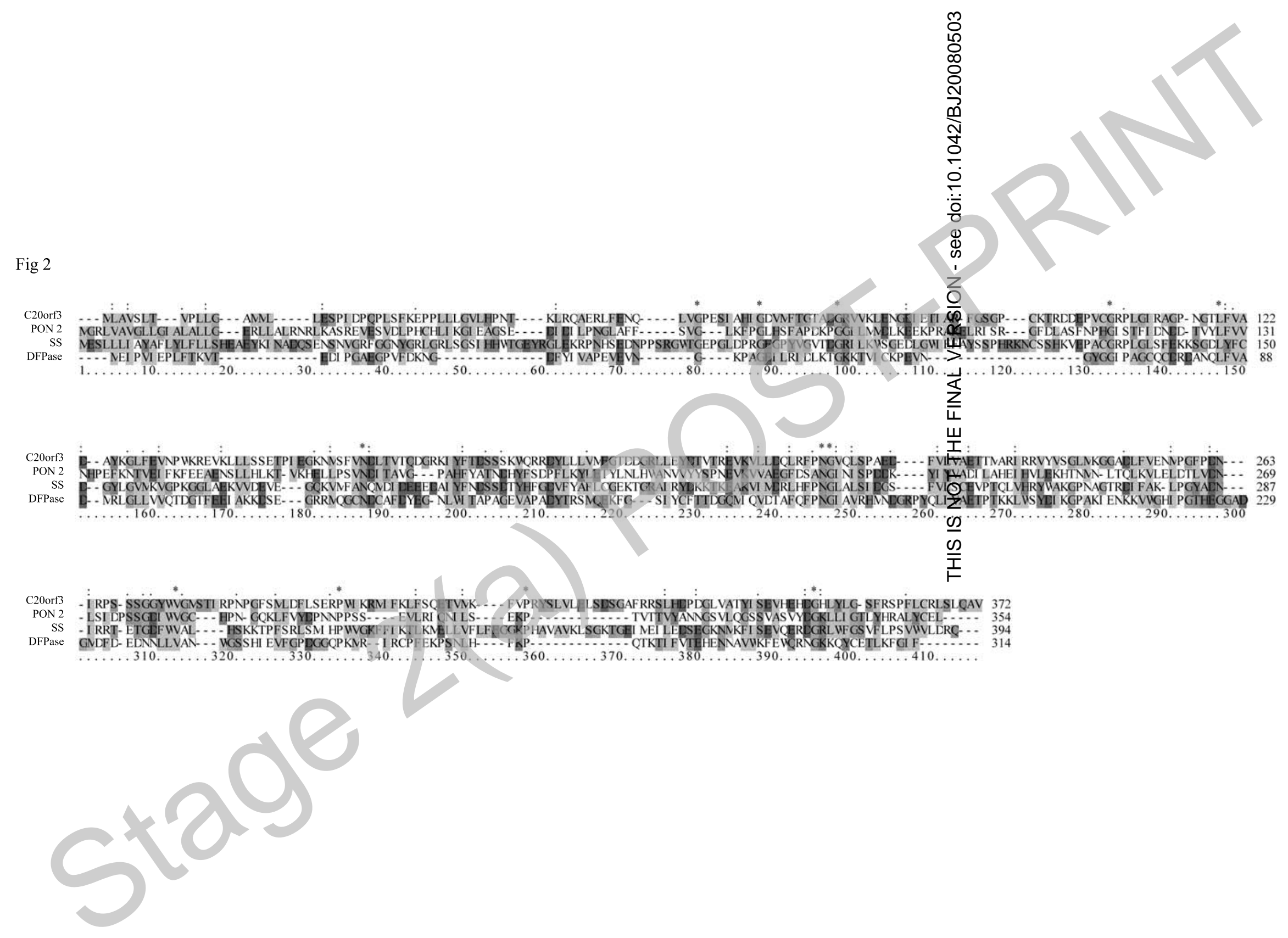

Licenced copy. Copying is not permitted, except with prior permission and as allowed by law. (c) 2008 The Authors Journal compilation (@ 2008 Biochemical Society 
Fig 4

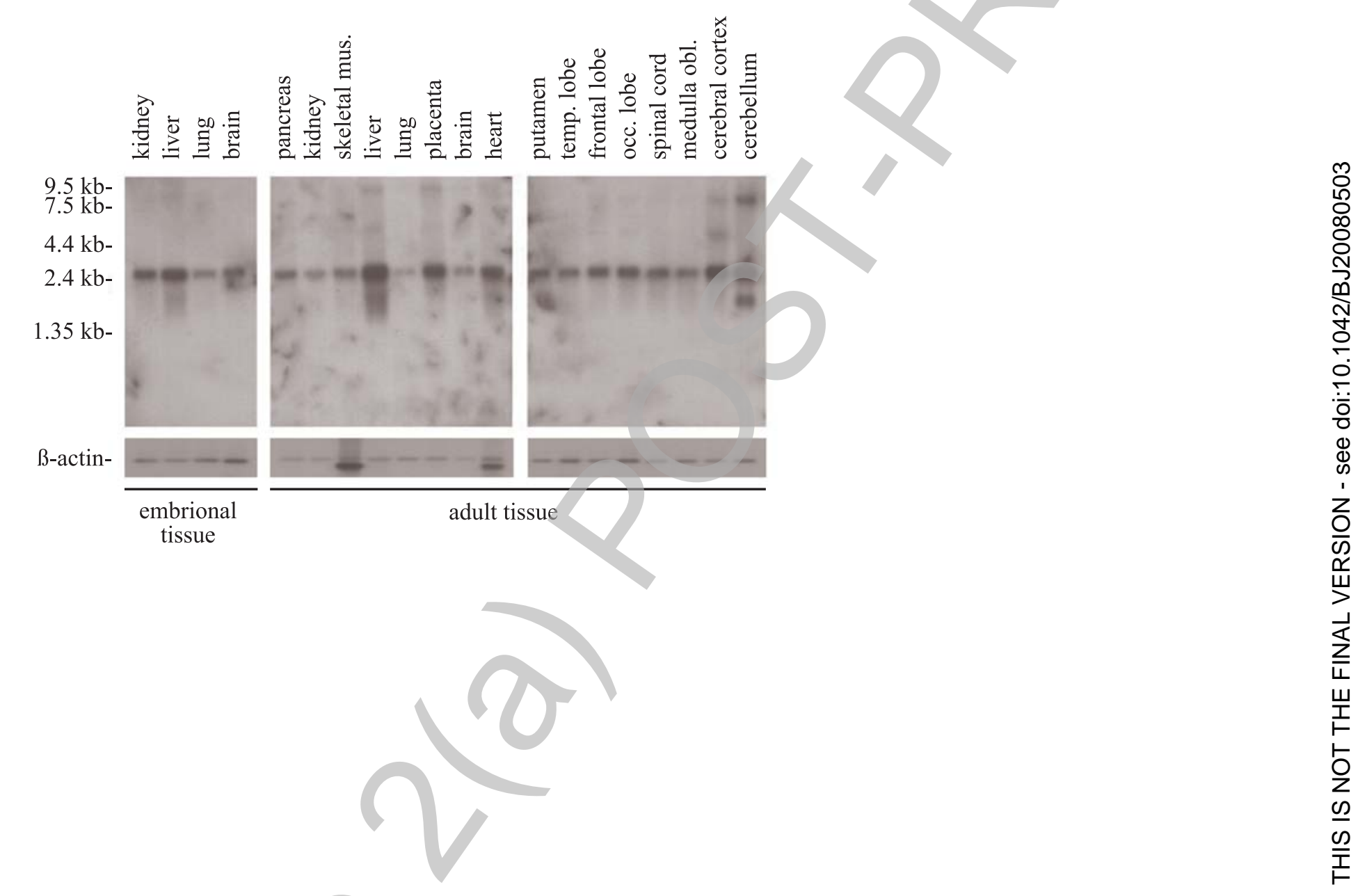




\section{Fig 5}

\section{$\mathbf{A}$}

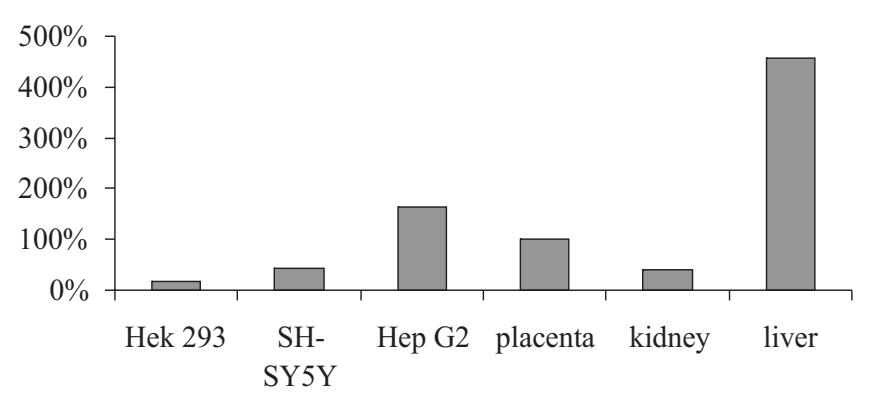

B

C

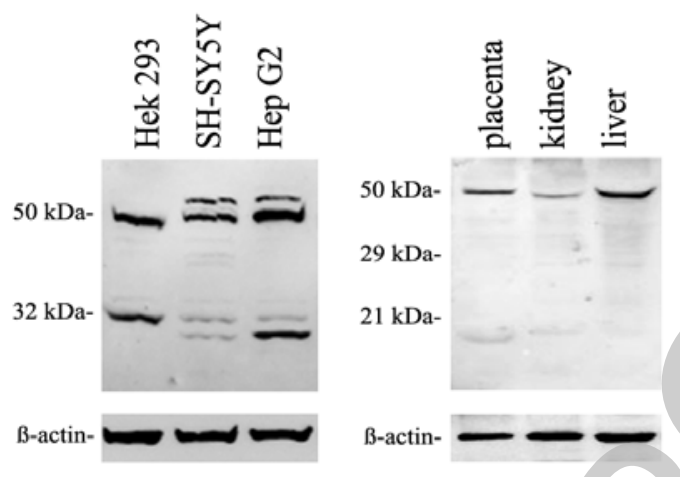


B Biochemical Journal Immediate Publication. Published on 30 May 2008 as manuscript BJ20080503

Fig 6
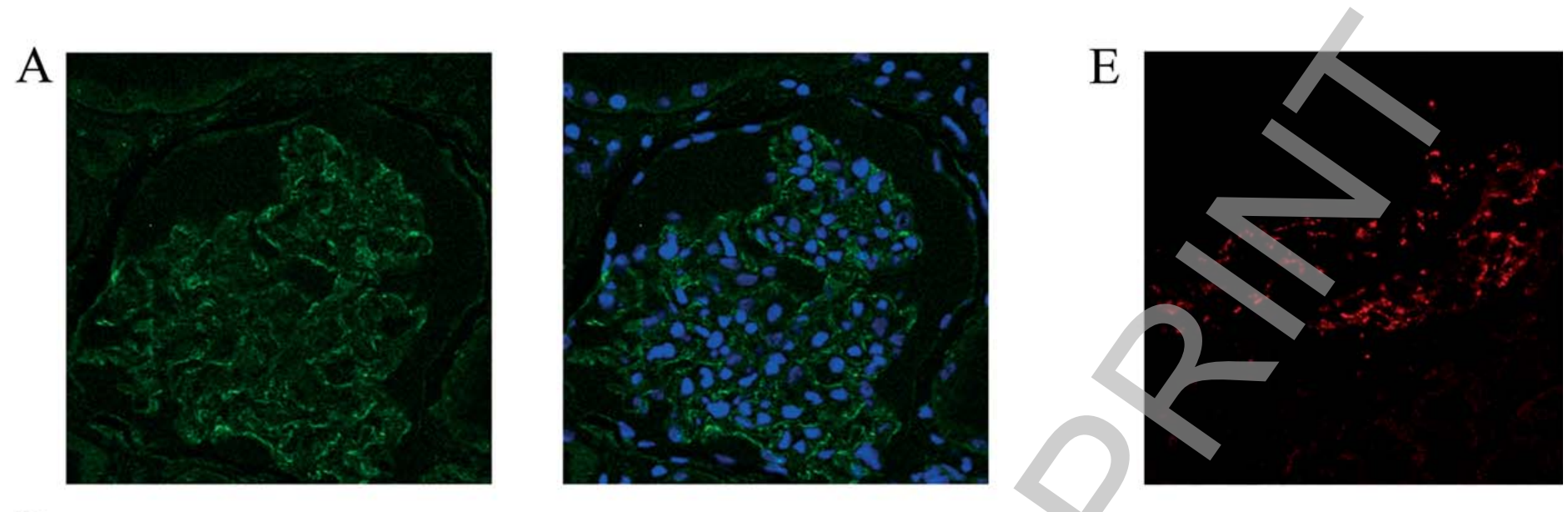

$\mathrm{B}$
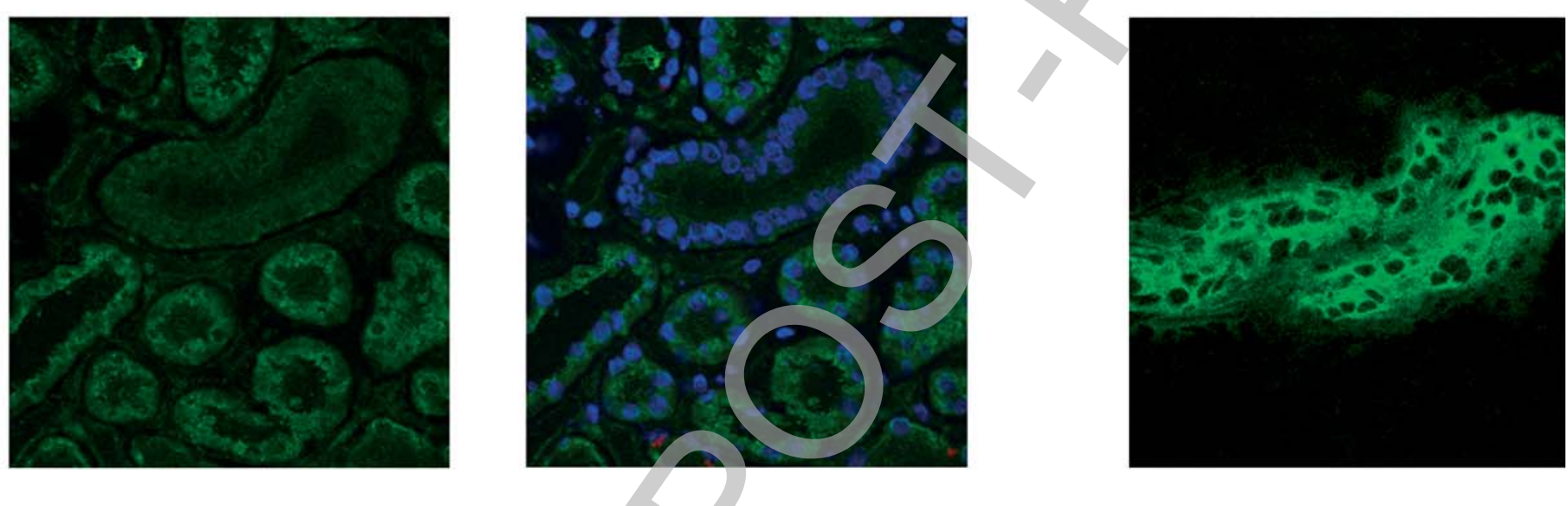

$\mathrm{C}$
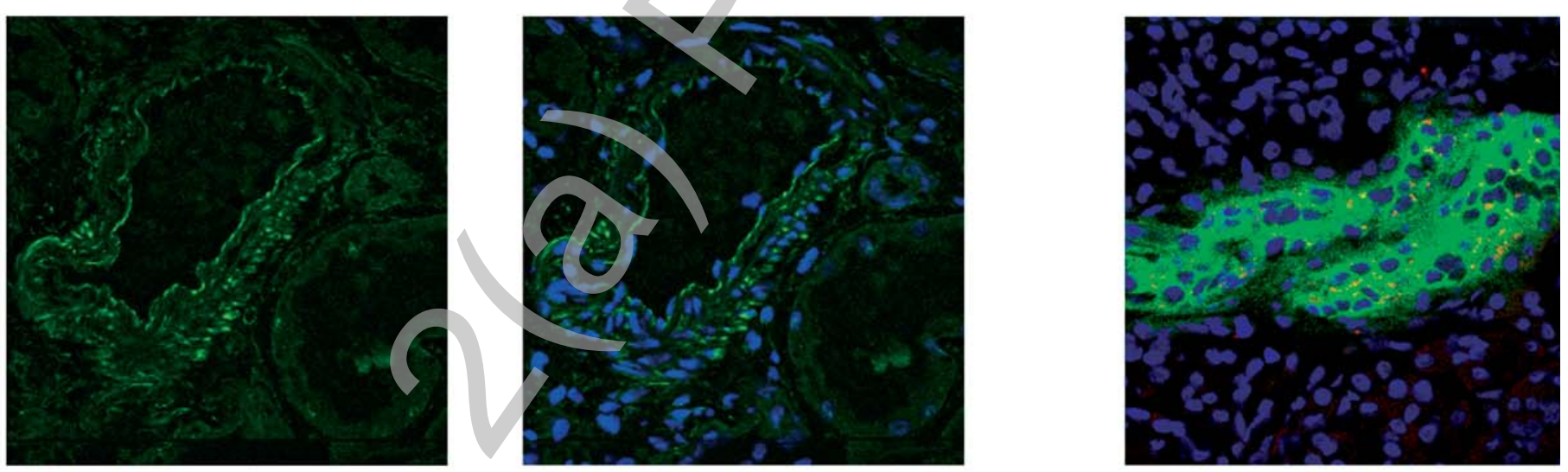

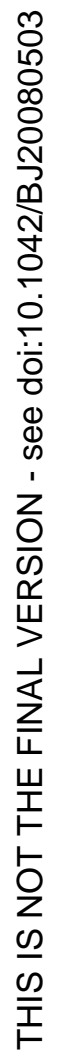
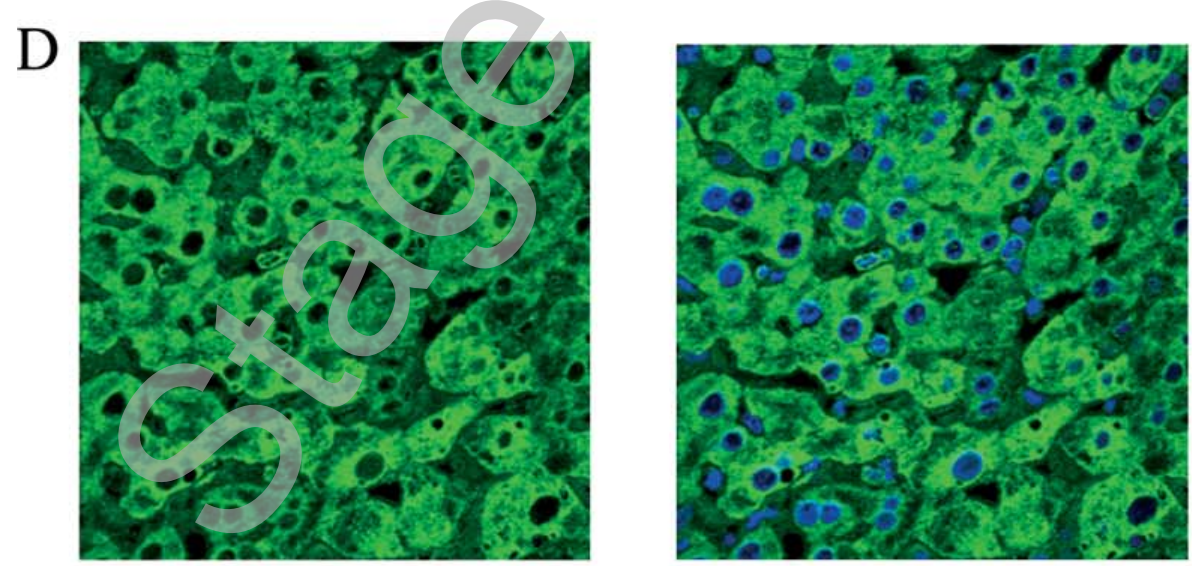

Licenced copy. Copying is not permitted, except with prior permission and as allowed by law. (C) 2008 The Authors Journal compilation (C) 2008 Biochemical Society 
Fig. 7

A

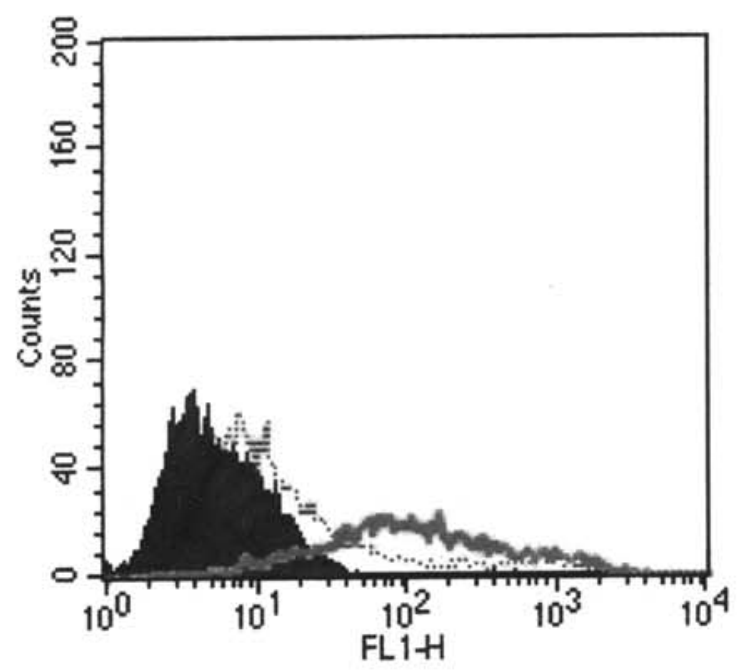

B

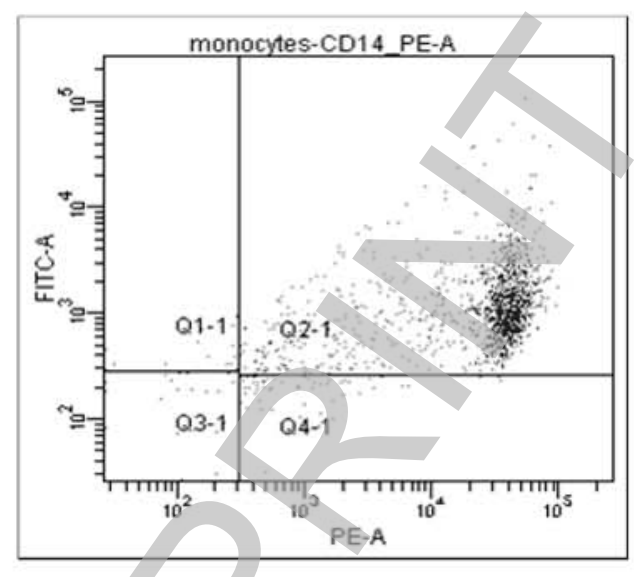


Fig $8 \mathrm{~A}$ 
Fig 8B

B
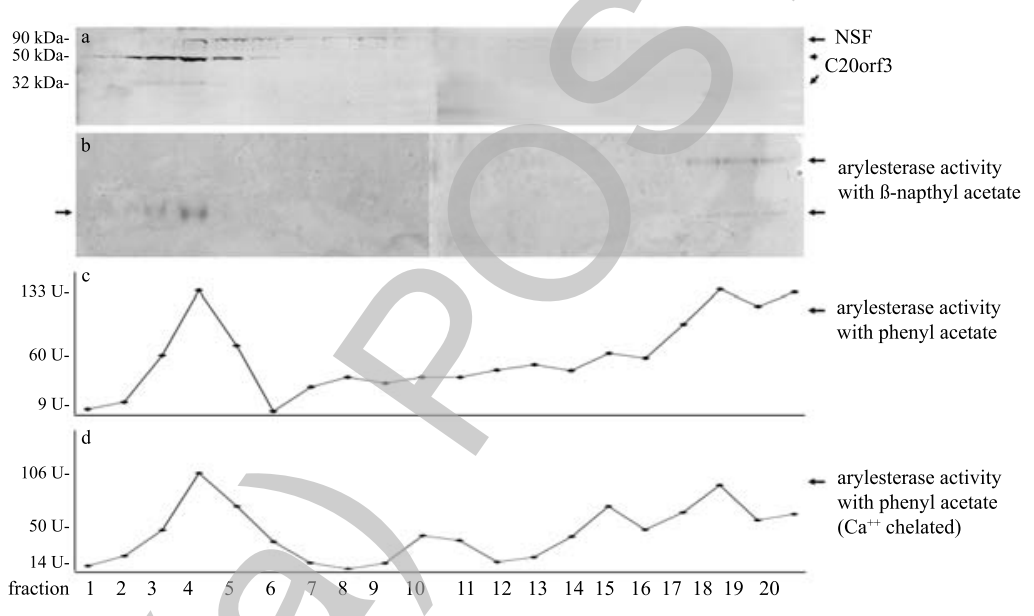

Licenced copy. Copying is not permitted, except with prior permission and as allowed by law. (C) 2008 The Authors Journal compilation (C) 2008 Biochemical Society 